\title{
The Myth Of Sustainability
}

\author{
Jan-Erik Lane ${ }^{1}$ \\ ${ }^{1}$ An independent scholar who has been full professor at 3 universities and visiting professor at many more \\ Correspondence: Jan-Erik Lane, 10 charles Humbert, 1205 Geneva, Switzerland. E-mail: janeklane@gmail.com
}

Received: August 25, 2014

Accepted: September 18, 2014 Online Published: November 26, 2014

doi:10.5539/jms.v4n4p161

URL: http://dx.doi.org/10.5539/jms.v4n4p161

\begin{abstract}
The concept of sustainability needs to be clarified. More specifically, ecological sustainability must take into account the recent findings about the risk of climate change and its consequences for the global environment. The constantly increasing amount of greenhouse gases poses the most serious threat to ecological sustainability, despite all efforts at green solutions.
\end{abstract}

Keywords: aspects of ecological sustainability, ecological capital, emission of greenhouse gases, economic growth or development, population growth, cornucopian fallacy

\section{Introduction}

The term "sustainability" has been employed now for decades in public discource and at international meetings, but what it stands for is still unclear. Speaking of "sustainability" fits nicely with green declarations, but what is it? This question is central in the debate between so-called cornucopians, who believe that sustainability is going up, and deep ecologists, who argue the opposite view. Which group, then is correct about the development of sustainability?

The UN has phrased a most general definition of the term:

Sustainable development has been defined in many ways, but the most frequently quoted definition is from Our Common Future, also known as the Brundtland Report. We quote:

"Sustainable development is development that meets the needs of the present without compromising the ability of future generations to meet their own needs. It contains within it two key concepts:

1) the concept of needs, in particular the essential needs of the world's poor, to which overriding priority should be given; and

2) the idea of limitations imposed by the state of technology and social organization on the environment's ability to meet present and future needs."

Moreover, "definitions of sustainable development require that we see the world as a system - a system that connects space; and a system that connects time." (Source: https://storify.com/lyingepic3398/what-is-sustainable-development).

This well-known concept of the UN of sustainability as "without compromising" the welfare of future generations is rather vague. When for instance the fish sturgeon has been overfished almost to extinction in e.g. Russia, then one may ask if this violates the requirement of sustainability, or perhaps people start fishing tuna instead or some other fish species? The question is whether sustainability is a static concept, based upon zero-sum condideraions, or it allows for dynamic aspects, like the discovery of new resources.

Here the conception of sustainability is linked to need fulfilment or welfare. Yet, often it is instead connected to resurces or the environment. The weakness of a needs based approach is that aggregation may be confused with distribution. Poverty reduction is considered extremely important in the UN policy bag, but is poverty amelioration part of sustainability? Poverty reduction could in priciple be promoted by redistribution from rich to poor countries or groups of people.

The second element in the UN approach - limitations on the technology as well as social organisation to protect the environment - is much closer to the concerns of the notion of sustainability. Yet, it target primarily technological issues and problems in social systems like e.g. the economy or the family, instead of focusing directly on ecological matters. It seems that there is a confusion of ends and means. Technology innovation and 
social organisation alternatives are tools for retrieval of ecological resources. They are to be sustained, not the tools in themselves.

In another UN document, one finds a heavier emphasis upon ecology:

The Rio+20 Outcome Document The Future We Want (Resolution 66/288, July 2012) highlighted the central role of technological cooperation for the achievement of sustainable development and requested relevant United Nations agencies to identify options for "a facilitation mechanism that promotes the development, transfer and dissemination of clean and environmentally sound technologies by, inter alia, assessing the technology needs of developing countries, options to address those needs and capacity-building". (Source: http://sustainabledevelopment.un.org/index.php?menu=1822)

Here, one encounters the idea of sustainable development, which is a dynamic conception. However, it is not defined directly in relation to the protection of environment assets but speaks more about needs and capacity building in poor countries. Fulfilling vital needs in huge countries like India, Pakistan, Bangladesh, China and Indonesia may require employing more environmental capital - how to handle this goal conflict?

It should be pointed out that one also encounters more diffuse definition of "sustainability", like the following:

"In more general terms, sustainability is the endurance of systems and processes. The organizing principle for sustainability is sustainable development, which includes the four interconnected domains: ecology, economics, politics and culture."

(Source: http://www.studyblue.com/notes/note/n/environmental-science-flash-vocab/deck/11770834)

Sustainability requires more than interconnectedness, it must be underlined. What this is can be searched for in the famous bet between cornucopian Simon and ecologists Ehrlich.

\section{Cornucopians Versus Ecologists}

In any approach to sustainability, there must be a clarification of what is to be sustained. Thus, sustainability in itself is an elliptic notion, as the pertinent question: sustainability of WHAT? I would be strongly inclined to argue for ecological capital, disregarding primarily technolo, social organisation and income distribution, although they are highly relevant to various issues surrounding ecological assets. Now, what objects or things figured prominently in the first real verger and the second suggested verger?

Sustainability as resource scarcity figured prominently in the first Simon and Ehrlich, targeting a list of measures of resource scarcity over from 1980 to 1990, including the commodity metals: copper, chromium, nickel, tin, and tungsten. Simon bet on price decrease, while Ehrlich bet on increase. It is generally agreed that Simon won the first verger, but is sustainability really the same as the maintenance of resources?

In the proposed second verger, which never took place with Simon declining, the emphasis was clealy upon ecological sustainability, as the ecologists put up the following predictions:

The three years 2002-2004 will on average be warmer than 1992-1994.

There will be more carbon dioxide in the atmosphere in 2004 than in 1994.

There will be more nitrous oxide in the atmosphere in 2004 than 1994.

The concentration of ozone in the lower atmosphere (the troposphere) will be greater than in 1994. Emissions of the air pollutant sulfur dioxide in Asia will be significantly greater in 2004 than in 1994. There will be less fertile cropland per person in 2004 than in 1994. There will be less agricultural soil per person in 2004 than 1994 . There will be on average less rice and wheat grown per person in 2002-2004 than in 1992-1994.

In developing nations there will be less firewood available per person in 2004 than in 1994. The remaining area of virgin tropical moist forests will be significantly smaller in 2004 than in 1994. The oceanic fishery harvest per person will continue its downward trend and thus in 2004 will be smaller than in 1994 . There will be fewer plant and animal species still extant in 2004 than in 1994. More people will die of AIDS in 2004 than in 1994. Between 1994 and 2004, sperm cell counts of human males will continue to decline and reproductive disorders will continue to increase. The gap in wealth between the richest $10 \%$ of humanity and the poorest $10 \%$ will be greater in 2004 than in 1994.

This is indeed a long list of projections, some environmental and others referring to social or economic balance. The upshot of this discussion is that one may wish to deal with a limited concept of ecological sustainability, targeting environmental capital. The decisive reason is knowledge and projectability. How to know whether resource sustainability is a temporary phenomenon or irreversible? Take the example of natural oil deposits versus shale oil and gasdeposits! 
Resource scarcity is dependent upon technological innovations besides the known existence of natural resources. Thus, explorations may discover new resources or types of them, but innovations may also generate entirely new kinds of resources.

Ecological sustainability is entirely a different matter, as it involves much of zero-sum considerations. Ecological capital is easily dissipated and may require hundreds of thousand years to be replenished. Thus, the pouring of mercury and lead into nature may result in irreparable damage. The notion of ecological sustainability ought to target the risk of irreversible damage to the global environment and its diversity of ecological contexts.

The essential concern for ecological sustainability deals with the prospect of the maintenance of the living consitions for all species in the global environment. One of the central aspects of this question is the occurrence of climate change and its ecological consequences.

\section{The Impact of Global Warming on Sustainability}

Ecological sustainability or the eqlibrium of environmental forces, in short ecological capital, covers many aspects, one of which is climate change. The extinction of species, the depletion of fish stocks, the pollution of fresh water and oceans as well as the spreading of garbage in the landscape may occur occur idependently of climate change. However, global warming is a real hammar upon mankind, as it may completely alter the conditions of life on the planet.

Climate change or global warming impacts upon mankind through its consequences upon:

a) land: warming the earth results in desertification, forest depletion and fresh water losses;

b) oceans: warming the sea gives rise to acidification, less nutrients at ocean floors as well as less uptake of carbon dioxide;

c) positive feedback lopes: warming the planet releases methane from frozen land and sea fuelling additional global warming, the barrier reefs will die reducing the efficiency of the carbon cycle, etc.

All these major effects, a) - c), constitute negatives for mankind. How come, then, that they nothing much is done to counteract them? We suggest that the most powerful human drive or motivation lies behind climate change, viz. materialism or self-interests.

\section{Emissions and Economic Development}

The emission of greenhouse gases has many sources: human beings, animals, land and sea deposits as well as the burning of fossil fuels, i.e. energy consumption.

The consumption of energy is essential in economic life. All countries aim at economic growth, especialy the rapidly developing economies with huge populations. The emissions of greenhouse gases must go up, as energy from renewable source is still in its infancy.

The connection between global emissions of carbon dioxide equivalent gases and economic activity can be anaysed by means of a few figures in order to find out how economic development increases the outpouring of emissions.

Thus, we have:

i) total emissions - GDP 2011 - all countries

Using most recently available information for Figure 1, we employ a cross-sectional regression model to serach for how advances in GDP augments total emissions of greehouse gases (GHG). 


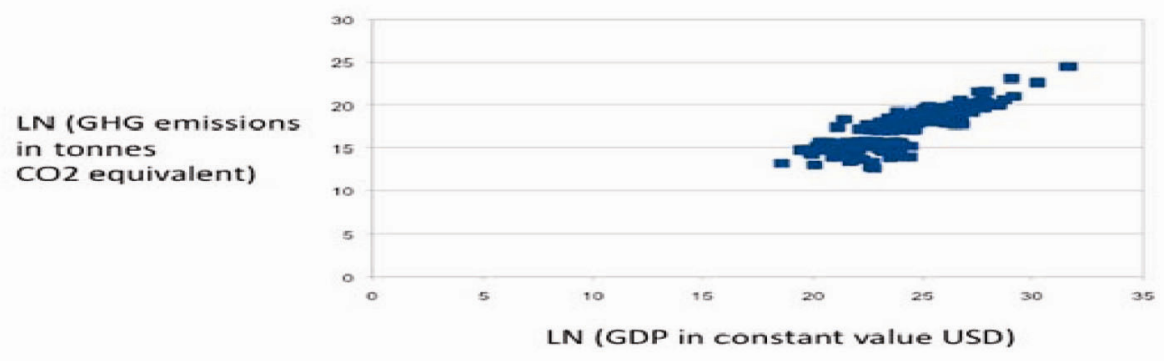

Figure 1. Emission and GDP (Equation: LN GDP - LN GHG Total: $y=0.81 x, R 2=0.708$ )

Note. GDP vs. Greenhouse emissions in 2011.

Sources: 1. World Bank Open Data, http://data.worldbank.org; 2. CAIT WRI 2.0: Climate Data Explorer, World Resources Institute, http://cait2.wri.org

In the global market economy, linking some 200 countries in a web of consumption and production, the variation in GDP is strongly linked with the total emission of greenhouse gases. This clear finding entails that the goal of reducing emissions in order to achieve ecological sustainability can only come by the massive use of carbon neutral energy consumption - not likely for decades ahead.

What counts for ecological sustainability is that the steady increase in emission of greenhouse gases stop and hope fully there will be a decline in total emissions. Yet, politicians and statespersons favour almost always economic growth ahead of ecological sustainability, when and if a reduction in total emissions would require a slowdown of economic development. Thus, the burning of fossil fuels shows no decrease and the forest areas keep declining.

ii) Emissions per capita - GDP per capita - all countries

Now, it has been argued that the advanced economiesare mainly responsible for global warming processes. If it were true, then emissions per capita would be strongly positively related to emissions per capita. Figure 2 suggests that it is not so.

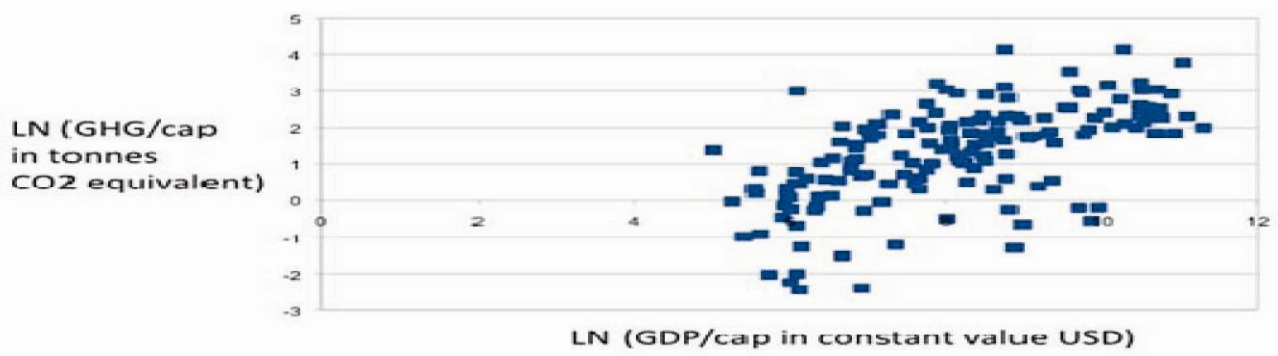

Figure 2. Emissions per capita and GDP per capita (Equation: LN GDP / CAP - LN GHG / CAP: $y=0.52 x$, $\mathrm{R} 2=0.370$ )

Note. GDP/capita vs. Greenhouse gas (GHG) emissions / capita for in 2011.

Sources: 1. World Bank Open Data, http://data.worldbank.org; 2. CAIT WRI 2.0: Climate Data Explorer, World Resources Institute, http://cait2.wri.org

The finding suggests strongly that emissions per capita is only weakly associated with gdp per capita. Thus, a few rich countries have rather low emissions, whereas some developing countries have substantial emissions per person. Thus, a global policy for econological sustainability is the responsibility of all countries on the globe, all people being concerned 


\section{Conclusion}

The notion of sustainability is a vague one, to be employed in much talk and little action. It involves different elements or aspects, only one of which is ecological sustainability.

Global sustainability is not enhanced as long astotal carbon equivalent emission increase, i.e. augments sharply year in and year out in reality. Two factors increasing greenouse gases are world population and economic activity:

Equation: Total greenhouse gases $=\mathrm{LN} \mathrm{GHG}=0.520 * \mathrm{LN}$ GDP $+0.477 * \mathrm{LN}$ Pop, $\mathrm{R} 2=0.76$.

This equation models the global situation today. One can imagine what happens to total emissions and ecological sustainability when world population reaches 9 billion and GDP doubbles. Basic global sustainability cannot take more than +2 degrees warming of global climate. The enormous increase in the amount of greenhouse gases the last 30 years has resulted in +1 degree increase in global warming. Given the link between overall economic activity and greenhouse gases, the future is bound to experience $>2$ degrees climate change, as $\mathrm{CO} 2$ equivalent emissions show no sign of being maintained, despite increased use of renewable energy sources.

Although much effort is being done in initiate the use of renewable energy, for instance solar power being used to supply electricity to a whole Chinese city (Solar Walley at Dezhou), it must be estalished that the total amount of greenhouse gases (GHG) keeps going up, year by year. This holds for carbon dioxide gases and non-carbon dioxide GHG. The CO2 emissions augment by a few percentages every year, despite all talk about renewable energy and ecological sustainability. It should also be pointed out that some efforts with renewable energy is subsidised by government, sometimes by countries with enormously high carbon footprint per capita, like the rich gulf states. Yet, the number of cars, airplanes and shipping vessels goes up all the time, as is also true of coal heated electricity generators. The consumption of meat has exploaded with the animals producing daangerous methane. ETC.

Not until the risks of global warming become part of the expectations of the global market players will they be taken seriously, meaning estimated as to economic consequences and if feasible counter-acted somehow. Sustainability has to be part of the rational expectations of the global markets. Figure 3 shows the extreme difficulty of all proposals to cut down the increase in greenhouse gases significantly, meaning $25-50$ per cent, in the coming decades. The greenhouse gases increase with the always expanding energy consumption (Figure $3)$.

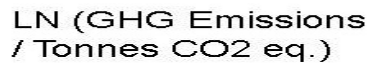
Tonnes $\mathrm{CO} 2$ eq.)

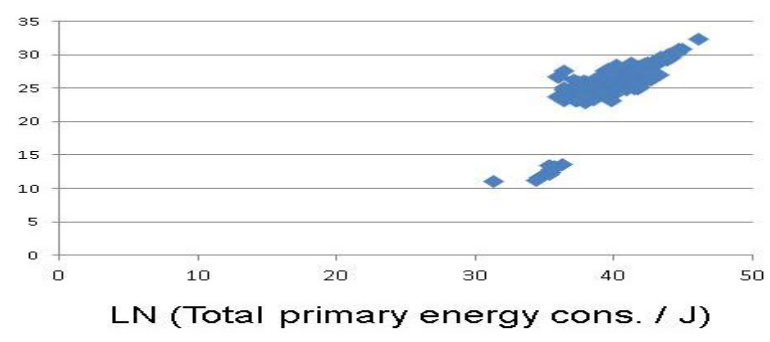

Figure 3. Total greenhouse gases and total energy consumption: Equation: Energy - emissions: $y=1,223 x, R 2=$ $0,616, \mathrm{~N}=173$

When energy consumption augments with one unit, then emissions increase with 1.2 units. And how is energy consumption, so vital to the fulfilment of human needs, be transformed in such a short time span towards C02 equivalent neutral technology?

\section{References}

Blewitt, J. (2008). Understanding Sustainable Development. London: Routledge.

Dresner, S. (2008). The Principles of Sustainability. London: Routledge.

Our Common Future. (1987). The World Commission On Environment and Development. Oxford: Oxford University Press.

Robbins, P. (2011). Political Ecology. Oxford: Wiley-Blackwell. 
Rogers, P., Jalal, K. F., \& Boyd, J. A. (2007). An Introduction to Sustainable Development. London: Routledge. U.S: Energy Information Administration (EIE)

World Resources Institute

World Bank national accounts data, and OECD National Accounts data files.

\section{Copyrights}

Copyright for this article is retained by the author(s), with first publication rights granted to the journal.

This is an open-access article distributed under the terms and conditions of the Creative Commons Attribution license (http://creativecommons.org/licenses/by/3.0/). 